（1）人工紫外線に依りても硫化護謨の酸化が促進せられ又遊維硫黃の減退を惹起するもその值 小なり日光の場合に於て見たる如き硬化の現象は本實驗に於ては見るてとを得ざりを其原因は光 線の强度弱きためなりしなるべし短波長部に富める紫外線を用ひても短時間に日光の場合に似た る變化を起さしむるためには相當の强度を必要とす人工光線を促進老化試驗に完全に應用するた めにはての默は考滤を要すべきー條件なり

（2）不活性瓦斯中に於ては光線の存在に於てる硫化護謨のアセトン抽出分は增加せす

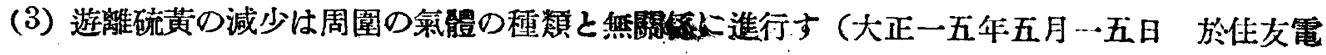
線製造所研究室)（大正一五年六月一五日受理）

\title{
硫化護謨の老化に關子る研究(第三報)天然護謨と 栽培生護謨の日光に依る變化の定性的比較
}

\author{
（火正一五年四月四日工業化學會第二九年會に於て講演）
}

工學士山崎 武二

緒 言

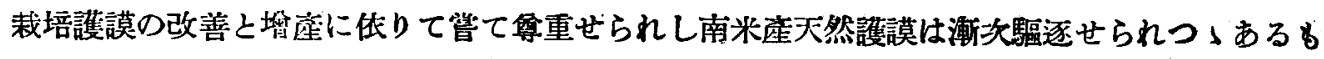
向特種の製品に於ては後者は今唒斯領域を有す著者は或種の研究と關聯して此兩者の性質に就い て目下定量的實驗を行ひつ」あるが茲に報告せんとするは最初に行ひし定性的試驗の中光線に体 る變化生起の遲速に關する部分なり

光線と關聯して天然護謨と栽培護謨の比較に關する研究は著者の知見の範圍內にては文献なし

實 驗 の 部

(I) 試料

(a) 試料の製作 ペールクレプ (Pale crepe)、スモークトシート (Smoked sheet) 级びファイン ハードパラ (Fine hard para) の3種をそれぞれベンッ゙ールに溶かしグーチ氏坩堝にて硝子毛を 用ひて滤過し蒸發法に訨り、て踭め濃㮦を知り次に之を用ひて硝子板上に極めて薄き同一の厚さの 皮膜を作る粎にし之を 1 種類の生護謨に就き 11 枚宛製作し同種類の8の 5 枚宛を 3 種類の生護 謨より取り 15 枚を以て 1 組として 2 組を作り殘りの 1 枚宛の 3 枚は直ちに暗所に貯へて比較の 標準とせり 
（b）試驗方法 實驗は大正一四年一○月一二日より同月一六日迄の 5 日間に亘る連續䫏驗にし てての期間內に著者の研究室屋上（海面上約 $10 \mathrm{~m}$ 前後）大大阪西北郊外六甲山（骠高 $927 \mathrm{~m}$ ）に 於て日光に暴露してその變化を觀察せり曝光方法は各組 15 枚全部を約 40 度の角度にて日光に 曝露し 1 日の曝露を終へたる後その變化を觀察し 1 種頻につき第一日に曝露の 1 枚宛を引き去り たる殘部を第二日目に日光に曝露し連日斯の如くして第五日目には最後迄殘れる 3 枚を取り入れ たりての際其各くに就て外觀の變化の他に粘度の變化の測定及ひ燃燒分析を行ふ像定なりしも賽 驗室屋上の試料は䗋煙のために山頂のものは砂、枯葉が多少附着せしためての測定は中止せり曝 光時間は午前八時より午後四時迄を普通としたり

\section{(II) 曝 露 試 驗}

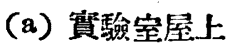

天候の概况氣 汥 $\left({ }^{\circ} \mathrm{C}\right)$ 午前八時 17

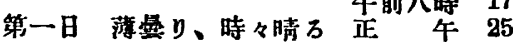
午後四時 21

雲深し 午前八時 16.5

第二日 午後三時より晴万 年袮四時 22.5

第三日 快 晴 午前八時 16.5 午後四時 22.5

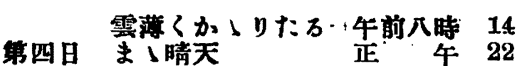
快晴約三時間年後吼時 21

第五日 暴天、午挠二時よ午前八時 15 䨋のた伂止. 正午 22
フォインハードパ スモークトンート ヘールクレプ

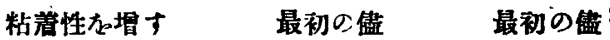

膜面透明になり表面 粘着力始め中央

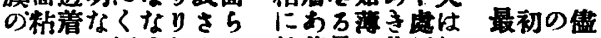

さらせる解感如與了、粘着最し甚だし

第二日目の輼の乾燥 狀息
粘着非常に激し 粘着し始も

膜面透明にな、包

表面の粘着热?

さ5さらしだる 乾燥狀息に入る

粘湆非常に湤し

粘着減じけっるい幾ら 加の粘り氯残万、復 牛日光にあて全了

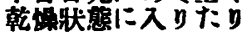

（b）六甲山頂（標高 $927 \mathrm{~m}$ )（筫駿の倜所は此より少し低し）

天候の概况

第一日 午前中晴天

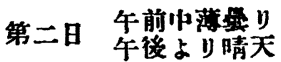

第三日 快 晴

第四日 午前中薄日

第五日 正午染薄是
氣 偲 $\left({ }^{\circ} \mathrm{C}\right)$ 午前八時 14 i正 午 16 午嵝些時 15 个前八時 10.5 正午 14 午前八時 12 iE 4 个 16 午媵四時 13 午前八時 10.5 正午 16 午後四時 14 午前八時 14.8 正午 16
ファインハードパ

非常に粘着す

膜面透明になり粘着

全くなくなり歹さ らせる乾蜗犾息に入 万

第二日の倎

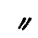

II
スモークトシート

最初の鰮

最初の雷

粘着し始し 最初の倎

粘着極めて甚だ 粘着し始む

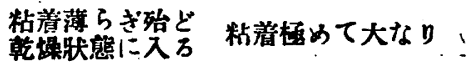

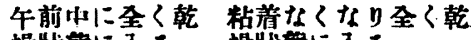

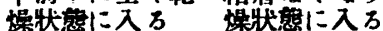

上記 (a).(b)兩賽驗の如くその外觀の變化を見るに兩地點に於て行ひし，ものは全く同一の變化 を巡り最初少しく粘着し始め次に非常に粘着甚だしき狀態に入りそれより粘着の度を減じて漸次 乾燥狀態に入る乾㷄狀態に入りたるものはベンソールに不溶性の透明なる酸化護謨皮膜を形成し さらさらせる触感を與ふ 
又同種の護謨に就いてはその孌化生起の荤速も全く同一にしてフ アインハードパラ最も速かに 粘着を始めて最も早く乾嬠狀態に入りスモークトシート之に次ぎペールクレプは最も荤る此の變 化が硫化後の性質と關係あるかは全く別個の問題なれど研究せば興味ある處ならむ又兩地默に於

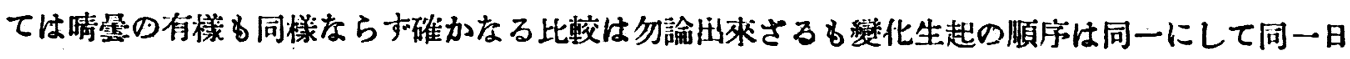

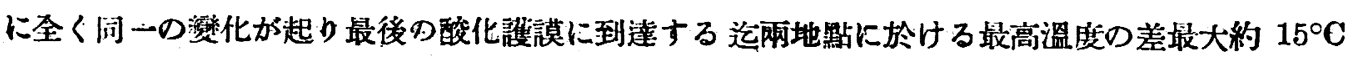
ありしにす拘らすそれを積極的に認㶩るてとを得さりしは第一報の結果と一政せるものと考ふ

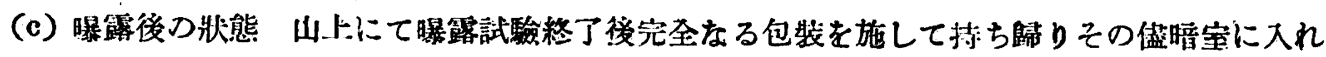
をきたるものを約 $41 / 2$ 月後に取出して檢したるに(大正一五年三月七日)

\begin{tabular}{|c|c|c|c|}
\hline 試料 & フアインメードバラ & $x モ-\eta ト \dot{*}-1$ & ヘールクレプ \\
\hline 第一日の分 & 乾燥狀態に在り & 少しく粘勫す & 試料製作當時の笽 \\
\hline 第二日の分 & 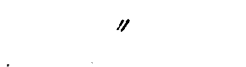 & 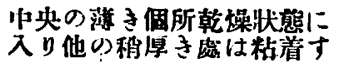 & 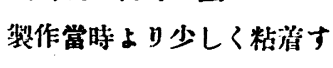 \\
\hline 第三日の分 & " & 全く乾焒狀意に在り & 全く乾燥状態に在り \\
\hline 第四日の分 & " & " & " \\
\hline 第五日の分 & " & 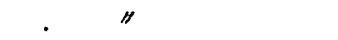 & " \\
\hline
\end{tabular}

なり之を山上に曝露當時の爿况と此較するに粘着を起しをらさるるのは $41 / 2$ 月阳喑所に聍蔵後 に於ても最初の㚝か或は幾らか粘着を起せり粘着し始めたる許りのるのは略その程度にて止まり 當時粘着の相當大なりしるのは眝藏中に乾燥狀態に入れるを見る即ち此の乾燥狀態に入る迄には 必ずー度粘着狀態 (Tacky state) を經過し且つての粘着が一定の狀態に達するてとを要す換言す れば生謢謨は或程度のデポリメリゼーションの階梯を經過するを要するるのと考へらるての結果 はゴルターキ及びフアンロッセム兩氏 (Whitly, Plantation Rubber \& Testing of Rubber, p. 105) 及び淺野氏 $(I . R . J ., 1925,70,352)$ の所論と一致す

研究結果の概要

（1）生绕謨が不溶性酸化護謨に到達する迄には必す一度粘着狀態を經過す

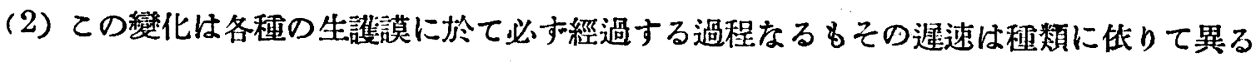

（3）溫度約 $15^{\circ} \mathrm{C}$ の差異ある約 3000 尺の高原と海面に近き地點とに於て定性的に全く同一の 結果を得たり此祭定性的なりしも光線の存在に於ける生護謨の酸化に溫庭の積極的影響を認むる ことを得ざりき

終りに臨み本研究の發表に當り種々付益なる御注意を與へられたる川上取締役並びに柴外線發 生怔㨁に就いて便宜を與べられたる淺野博士に深謝つ意を表す

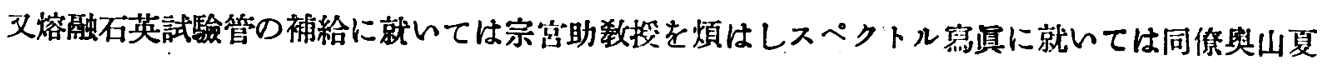
六君の援助を受けたり共に記して謝澺を淩す(大正一五年五月一五日 於任友電線製造所研究至)

追記 本研究を四月四日工業化學會年會に發表後五月に到着せし Ind. Eng.Chem., 1926, 18， 420 に於てゼカスコ氏（F. P. Jecusco）の促進老化試驗に光線を加へたる研究報告に接したり 